RESEARCH ARTICLE

\title{
EFFECTIVENESS OF TREATMENT AND RECOVERY OF DOMESTIC VIOLENCE VICTIMS ON SEMARANG REGENCY
}

\author{
Christophorus Divo Shubma Cahyaningutomo \\ Pangudi Luhur Tarcisius Vocational School \\ $\triangle$ christopherdivo@yahoo.com
}

\section{CITED AS}

Cahyaningutomo, C.D.S. (2020). Effectiveness of Treatment and Recovery of Domestic Violence Victims on Semarang Regency. Journal of Law and Legal Reform, 1(3), 425-436. DOI: https://doi.org/10.15294/jllr.vli3.36702

\begin{abstract}
Housekeeping is the smallest community of a society. Household a happy, safe, and secure into everyone's dream. Wholeness and harmony of a household can be impaired if the attitude, behavior, and self-control cannot be controlled. Ultimately can occur domestic violence causing insecurity or injustice against people who are within the scope of the household. From the result of the violence, the victim should be restored to rise physical and psychological conditions. Inhibiting factors is a recovery of victims of domestic violence is that most of the victims do not want to restore condition, efforts to resolve it provides socialization, convincing victims of domestic violence to want to restore, to supervise the victims have been recovered. Supporting factors is the facility is being used in the recovery process is adequate, the victim does not charge at all during the recovery process. In conclusion, the service process and the recovery of victims of domestic violence conducted by the relevant institutions have been equally effective and in accordance with the legislation in force.
\end{abstract}

Keyword: Effectiveness; Implementation; Recovery; Treatment; Domestic Violence 


\section{TABLE OF CONTENTS}

\begin{abstract}
TABLE OF CONTENTS

INTRODUCTION

METHOD

EFFECTIVENESS OF TREATMENT AND RECOVERY OF DOMESTIC

VIOLENCE VICTIMS ON SEMARANG REGENCY

OBSTACLES TO THE IMPLEMENTATION OF RECOVERY OF VICTIMS

OF DOMESTIC VIOLENCE AND EFFORTS TO OVERCOME THEM ......

CONCLUSION

REFERENCES
\end{abstract}

425

\section{INTRODUCTION}

Domestic violence involves violent and/or controlling behavior that is intentional and perpetrated by an individual towards a current or former intimate partner. This form of violence has been a persistent and significant problem in Canada and the US. Although men can be victimized by this violence, women have been disproportionally represented as victims, as they are almost four times more likely than men to experience domestic violence (Reif and Jaffe 2019).

Patients may present with both physical and mental disorders resulting from the abuse, as stress from the trauma can lead to years of health problems, depression and anxiety. Unfortunately, many clinicians lack the skills and understanding to identify domestic violence at the onset of treatment, posing a considerable danger to the patient. The doctor may be treating a patient for somatic complaints and depression, yet the victim may not discuss domestic violence until months later, if at all (Buel 2002).

In the United States, approximately one in six children have witnessed domestic violence (DV) in their lifetimes, and more than one in five have witnessed other assaults in their families. This type of violence exposure has serious implications for youth, increasing the risk for a range of problems including mental illness, substance use, delinquency, and academic and learning challenges. Police often serve as first responders to domestic violence incidents. As such, they are in a unique position to identify children exposed to trauma and potentially reduce its deleterious effects. Increasingly, cities and municipalities are attempting to incorporate police officers in a more coordinated response to DV, one in which police roles shift from punitive (e.g., investigation and arrest) to advocacy (e.g., assessing victim and family safety and facilitating connection to additional services) (Stevens et al. 2019; Andhini $\&$ Arifin 2019; Setyaningrum \& Arifin 2019; Juliana \& Arifin 2019).

Domestic violence (DV) is an increasing, complex global public health concern (Ruddle, Pina, and Vasquez 2017). Psychopathology is a common consequence of childhood abuse, as well as an independent risk factor for child abuse potential 
(Anderson et al. 2018). This situation of domestic violence is usually caused by family members or intimate partners and frequently within the house (Cobos-Cali et al. 2018). Violence and the fear of violence are emerging as an important risk factor contributing to the vulnerability to human immunodeficiency virus (HIV) infection for women (Patrikar et al. 2012). The recognition of domestic violence as a social and political issue has contributed to the progressive identification of a serious situation, considered in 2002 by the World Health Organization (WHO) as a public health problem with associated consequences which are devastating to the health and wellbeing of those who suffer it and to the development of the child, family, community and society as a whole (Coutinho et al. 2015).

In contrast to the common strategies employed in interventions in the United States of America (USA), Scourfield (1998) emphasizes that domestic violence intervention programs in the United Kingdom (UK) are more likely to involve theoretical approaches based on cognitive behavior, psychodynamics and feminism. Domestic violence intervention programs' models mostly include cognitive-behavioral therapy, feminist therapy, the Duluth model, motivational interviewing, individual and psychodynamic counseling (Erum, Dam, and Deyn 2019).

\section{METHOD}

The method is essentially a procedure in solving a problem and to gain scientific knowledge, the work of a scientist will be different from the work of a layman. Research is an attempt to find the truth or to better provide truth. In this thesis, the research method used is qualitative research methods. The data collection techniques in this research are the study of literature. After the data is collected then it is processed and tested for its validity using triangulation techniques to draw conclusions.

\section{EFFECTIVENESS OF TREATMENT AND RECOVERY OF DOMESTIC VIOLENCE VICTIMS ON SEMARANG REGENCY}

The implementation of recovery of victims of domestic violence carried out in Semarang Regency by the Semarang District Social Service, the Semarang Regency Family Planning and Women's Empowerment Agency, and the Semarang Police Resort are carried out in accordance with applicable laws and regulations. This recovery process has procedures that must be implemented including reporting to one of the agencies authorized to carry out the recovery of victims of domestic violence. In 2015 the number of victims of domestic violence according to BKBPP was 100 people and according to the Semarang Police Resort there were 13 people, in the JanuarySeptember 2016 period the number of victims of domestic violence recorded by BKBPP 
was 65 people and according to the Semarang Police Resort in 2016, there were 10 people.

To find out whether the implementation of recovery of victims of domestic violence has been going well and effectively, it can be seen from the following table data, among others:

Table. 1 Data on Implementation of Recovery for Victims of Domestic Violence

\begin{tabular}{clccc}
\hline No. & Government Agencies & Male & Female & Amount \\
\hline 1 & Polres Semarang & 0 & 4 & 4 \\
2 & RSUD Ungaran & 9 & 7 & 15 \\
3 & RSUD Ambarawa & 15 & 11 & 26 \\
4 & Badan KBPP & 0 & 4 & 4 \\
5 & Others & 2 & 13 & 15 \\
\hline TOTAL NUMBERS OF VICTIMS & & & 65 \\
\hline
\end{tabular}

Shelters are now seen as a standard source of emergency protection from domestic violence, provided by governments and charities. Shelters also provide a crucial base for women and children to access support services and develop long-term strategies for escaping abusive relationships (Prenzler and Fardell 2017).

As noted above, many domestic violence shelters deny access to services to women with active substance use disorders. Among those that allow women with substance use disorders to access resources, programs vary in the treatment options available to women (Schumacher and Holt 2012). A violent episode can be a single act, or a series of violent acts that may persist over a period of minutes, hours, or days. A violent episode may involve single or multiple types of violence (e.g. physical violence, sexual violence, psychological or emotional abuse, or all three types together) (Fanslow 2017; Muntamah, Latifiani, \& Arifin 2019; Kemala Dewi \& Arifin 2019). Domestic violence is the most common violence to which women are subjected; unlike the situation for men, who are more likely to be assaulted by a stranger or acquaintance. Often, various types of violence coexist within a marital relationship. The woman may be a victim of physical, sexual, verbal or psychological abuse (Boughima and Benyaich 2012).

Many studies have demonstrated the importance of children exposed to domestic violence in developing behavioral, emotional, and cognitive difficulties (Chan and Wong 2019).

Violence against the spouse affects the person and usually causes external injuries needing treatment, and leaves internal or mental injuries remaining, which may not be visibly apparent throughout the victim's life. It also affects family members, especially young children or teenagers who are severely affected mentally, making them emotionally repressed, aggressive, roguish, and they become inattentive students. Domestic violence causes divorces, children run away from home and become homeless and eventually social problems. These events in turn greatly affect the country not only socially but also economically, especially in terms of medical treatment, social welfare, counseling services for victims of domestic violence, and the 
implementation of preventive measures, and such violence also causes children to learn and absorb it (Laeheem 2017).

From the table data above it can be seen that the number of victims of domestic violence handled and reported by the Semarang Police to BKBPP were 4 people consisting of 0 men and 4 women, Ungaran Regional Hospital as many as 15 people consisting of 9 men and 7 female, Ambarawa Regional Hospital as many as 26 people consisting of 15 men and 11 women, BKBPP as many as 4 people consisting of 0 men and 4 women, and another as many as 15 people consisting of 2 men and 13 women. The number that has been handled by BKBPP through P2TP2A Unit in the JanuarySeptember 2016 period is 43 people and 22 people have not been handled.

Table. 2 Data on Recovery of Victims of Domestic Violence according to BKBPP in Semarang Regency Period 2015

\begin{tabular}{clccc}
\hline No. & Districts & Male & Female & Amount \\
\hline 1 & Ambarawa & 14 & 18 & 32 \\
2 & Brancak & 0 & 1 & 1 \\
3 & Bandungan & 4 & 14 & 18 \\
4 & Banyubiru & 4 & 8 & 12 \\
5 & Bawen & 2 & 11 & 13 \\
6 & Bergas & 1 & 7 & 8 \\
7 & Bringin & 1 & 2 & 3 \\
8 & Getasan & 0 & 2 & 2 \\
9 & Jambu & 0 & 4 & 4 \\
10 & Kaliwungu & 0 & 0 & 0 \\
11 & Pabelan & 0 & 0 & 0 \\
12 & Pringapus & 1 & 8 & 9 \\
13 & Sumowono & 1 & 3 & 4 \\
14 & Suruh & 1 & 3 & 4 \\
15 & Susukan & 0 & 1 & 1 \\
16 & Tengaran & 0 & 1 & 1 \\
17 & Tuntang & 7 & 3 & 38 \\
18 & Ungaran Barat & 9 & 29 & 28 \\
19 & Ungaran Timur & 6 & & 100 \\
\hline \multicolumn{5}{r}{ TOTAL NUMBERS OF VICTIMS } \\
\hline
\end{tabular}

It may be necessary to have different intervention methods according to the participants' cognitive developmental levels. Participant Cera, for example, was 10 years old and in the formal operational period. She could express her thinking verbally and be thus able to discover positive psychological resources through conversation with the therapist and verbalize her experiences in sessions (Kang 2017).

According to the Turkish law titled "Law to Protect Family and Prevent Violence against Women number 6284," domestic violence is defined as every instance of physical, sexual, psychological, and economic violence occurring between 
family members or between other people presumed to be family members regardless of whether the victim and perpetrator of domestic violence live in the same home. In particular, the law defines violence against women as violent behavior (as defined previously) that is executed because of a woman's gender or behavior that violates human rights by discriminating based on gender (Özçakar et al. 2016).

From the table data above it can be seen that the number of victims of domestic violence reported to the KBPP Agency and handled by the KBPP Agency in the period of 2015 were 100 people consisting of 32 Ambarawa Districts (14 Men and 18 Women), Bancak District 1 People (1 Woman), Bandungan District 18 People (4 Men and 14 Women), Banyubiru District 12 People (4 Men and 8 Women), Bawen District 13 People (1 Man and 12 Women), Bergas District (1 male and 7 female), Bringin subdistrict 3 people (1 male and 7 female), Getasan sub-district 1 person (1 female), Jambu sub-district 4 people ( 4 female), Pringapus sub-district 9 people (1 male-male and 8 female), Sumowono sub-district 4 people (1 male and 3 female), Suruh sub-district (1 male and 3 female), Susukan sub-district 1 person ( 1 female), Tengaran sub-district 1 person (1 female), Tuntang District 9 people ( 7 men and 2 women), Ungaran District Ba rat 38 people ( 9 men and 29 women), Kecamatan Ungaran Timur 28 people (6 men and 22 women).

So the performance of the Semarang Regency Social Service, the Semarang Regency Family Planning and Women's Empowerment Agency, and the Semarang District Police in carrying out the process of recovering victims of domestic violence in the January - September 2016 and 2015 periods can be said to be effective (right on target) because they have met elements of effectiveness, namely quantity, quality and time that have been achieved. For example, in the January - September 2016 period of 65 domestic violence victims reported to the Semarang Regency KBPP Agency 43 have been successfully recovered and returned to the place of origin of the victims and 22 others are still in the process of recovery. successfully recovered 100 victims of domestic violence from 100 cases reported to the KBPP Agency, so it can be seen that the performance of the Semarang District Social Service, the Family Planning and Women's Empowerment Agency and the Semarang Police have been effective (on target) and efficient.

Victims are accompanied by a staff member from the police in order to make a proper follow up of the case. The victims of domestic violence don't pay anything for health care services. Mediation: Some cases of domestic violence are solved through mediation whereby some perpetrators commit themselves that they won't commit the same act (Mukashema 2014).

Considering optimizing support for diverse survivors, the DV community recently has focused on the inter-relationship between gender norms, socioeconomic status, race, culture, and immigration disparities. Often referred to as an "intersectionality framework", using an intersectional approach can give a voice to marginalized women, challenge stereotypes of the "typical" DV survivor, and highlight the need for culturally-tailored resources. In response to this less monolithic framework of viewing DV survivors' experiences, culturally-specific DV agencies have been emerging over the past 10-20 years. Staff at these agencies provide culturally- 
tailored expertise to DV survivors who belong to marginalized, isolated, or otherwise hard to reach groups (Ragavan et al. 2018).

According to the World Health Organization violence is the intentional use of physical force or power, threatened or actual, against oneself, another person or a group or community, which either results in or has a high likelihood to cause injury, death, psychological harm, development disorder or deprivation. Domestic violence (DV) is a complex and common social phenomenon that takes place in the private domain: among couples or family members (Sánchez-Guzmán et al. 2017). Domestic violence against women is a widespread phenomenon worldwide, affecting one out of three women aged 15 and over (La Mattina 2017)

The Social Service in carrying out its function and role as the organizer of recovery of victims of domestic violence has performed its function properly, which is obliged to provide counseling to the reporting corps, then after receiving the report and providing counseling and interviewing the victim is offered whether he wants to proceed to the law or prefer to do mediation and peace if the victim prefers to take legal action then the victim will be accompanied by a social worker to report to the Semarang Police if the victim chooses peacefully then the victim will be found with a perpetrator of domestic violence to mediate. The risk for domestic violence assault has been studied longer than the risk for recidivism, so it is not surprising that less is known about the risk for post-treatment recidivism. However, clinical treatment issues have motivated much of the recent research, and clinicians and policymakers have become more concerned with the effectiveness of the interventions. Research has concentrated on treatment response (e.g. The Family Planning and Empowerment Agency through the P2TP2A Unit has the following functions and roles to accompany victims to the hospital to conduct a Visum Et Repertum and first treatment, after which the victim is accompanied to report the incident to the Semarang District Police. After conducting treatment at the hospital and making a report at the Semarang police station, the victim will be asked if he wants to continue to the legal route or prefer the mediation path, if the victim chooses the mediation path and prefers to return to his family, the victim will be charged Rp. 500,000, - if the distance of the house is far, if the distance of the house is close then the victim is not given a fee. If the victim feels scared to return to her house, the victim by members of the P2TP2A BKBPP unit is escorted to the Wira Adhi Karya shelter to recover her condition. All costs start from conducting a Visum, covering all costs of care for victims of domestic violence to the cost of returning the victims of domestic violence.engaging in physical violence against one's partner after treatment) (Sartin, Hansen, and Huss 2006).

The Family Planning and Empowerment Agency through the P2TP2A Unit has the following functions and roles to accompany victims to the hospital to conduct a Visum Et Repertum and first treatment, after which the victim is accompanied to report the incident to the Semarang District Police. After conducting treatment at the hospital and making a report at the Semarang police station, the victim will be asked if he wants to continue to the legal route or prefer the mediation path, if the victim chooses the mediation path and prefers to return to his family, the victim will be charged Rp. 500,000, - if the distance of the house is far if the distance of the house is close then the victim is not given a fee. If the victim feels scared to return to her house, 
the victim by members of the P2TP2A BKBPP unit is escorted to the Wira Adhi Karya shelter to recover her condition. All costs start from conducting a Visum, covering all costs of care for victims of domestic violence to the cost of returning the victims of domestic violence. Physical assaults by men against their female romantic partners also referred to as intimate partner violence (IPV), represent an important social problem. Intimate partner violence results in serious physical injuries and psychological distress for its victims (Schumacher, Fals-Stewart, and Leonard 2003).

] demonstrated that yogic breathing alone and in combination with the act of giving testimony, reduced partner violence survivors' depressive symptoms more than the control condition (Clark et al. 2014). The subjects were included in the protocol and were referred to different treatment centers to receive psychotherapy, not to take part specifically in experimental design (Tarquinio et al. 2012). Witnessing violence is a key form of $\mathrm{CV}$ with detrimental effects on physical and mental health. To protect children from transgenerational cycles of violence, early intervention is necessary. Psychosocial intervention can include better self-care, functional coping strategies (Riedl et al. 2019).

\section{OBSTACLES TO THE IMPLEMENTATION OF RECOVERY OF VICTIMS OF DOMESTIC VIOLENCE AND EFFORTS TO OVERCOME THEM}

A child or adolescent who has experienced direct victimization of abuse is more likely to exhibit internalized symptoms (An et al. 2017). Specifically, the aim was to determine if DV-exposed children disproportionately attend to angry faces compared to non-exposed children and whether this bias in attention was associated with child social-emotional problems. The results were intriguing. Young children with a history of DV-exposure, compared to those without, showed equal attention to the non-face stimulus they were assigned to find (i.e., a cartoon hippo); however, they had a significantly and substantially lower duration of fixation on sad and neutral faces. Anger and happiness were the emotions for which DV-exposed children's fixations were equivalent to those of non -exposed children (Mastorakos and Scott 2019).

Domestic violence can be classified according to the actions into three types as follows. Type 1 is physical violence, which refers to the use of force or a tool as a weapon to hurt the victim such as pushing, slapping, hitting, punching, beating, jerking, squeezing the neck, throwing thing at, and injuring severely with a weapon or a sharp object, etc. Type 2 is mental violence, which refers to any action or ignoring to act which causes the victim sorrow or losing rights or freedoms by doing it verbally or through gestures and action such as verbal despising, satirizing, scolding, bawling, yelling, embarrassing, being indifferent, threatening, showing anger, etc. Type 3 is sexual violence, which refers to the incident when a husband abuses his wife, a father 
abuses his children, an elder relative such as a brother, an uncle, a grandfather abuses his younger relatives, etc. (Laeheem 2016).

In the implementation of the recovery of victims of domestic violence, there are obstacles experienced when carrying out the process of recovery of victims that is that victims usually do not want the case to be processed through legal channels because the victim feels afraid, besides the victim also feels afraid if his condition is restored at the shelter.

\section{CONCLUSION}

The implementation and cooperation in the recovery of victims of domestic violence carried out by the Semarang District Social Service, the Family Planning and Empowerment Agency for Women and the Semarang District Police to their victims have been effective and tried as best they can as actions to restore the conditions of victims of domestic violence, as stated in Article 2 Government Regulation No. 4 of 2006 concerning the Implementation and Cooperation for the Recovery of Victims of Domestic Violence, But even so, there are still a number of things that victims feel have not met the standards. For example, in terms of ease in terms of reporting that there has been violence in the household and the difficulty of eliminating trauma that has arisen as a result of acts of violence committed against victims. In addition, there are still often people who do not want to report related to acts of violence in the household.

\section{REFERENCES}

Anderson, R.A.E., Edwards, L.J., Silver, K.E., \& Johnson, D.M. (2018). Intergenerational Transmission of Child Abuse: Predictors of Child Abuse Potential among Racially Diverse Women Residing in Domestic Violence Shelters. Child Abuse and Neglect 85(1), 80-90. https://doi.org/10.1016/j.chiabu.2018.08.004.

Andhini, A.S.D., \& Arifin, R. (2019). Analisis Perlindungan Hukum Terhadap Tindak Kekerasan pada Anak di Indonesia. Ajudikasi: Jurnal Ilmu Hukum 3(1), 41-52. DOI: http://dx.doi.org/10.30656/ajudikasi.v3il.992.

Arifin, R. (2020). Crimes and Society, How Do the Law Respond to Disruptive Conditions?. Law Research Review Quarterly,6(1), i-iv. Retrieved from https://journal.unnes.ac.id/sju/index.php/snh/article/view/37437.

Arifin, R. (2020). Legal Services and Advocacy in the Industrial Revolution 4.0: Challenges and Problems in Indonesia. Indonesian Journal of Advocacy and Legal Services, 1(2), 159-162. https://doi.org/10.15294/ijals.vli2.36488.

Boughima, F. A., \& Benyaich, H. (2012). Domestic Sexual Violence (Descriptive Study 
of 28 Cases). Sexologies 21(1), 16-18. http://dx.doi.org/10.1016/j.sexol.2011.08.011.

Buel, S. M. (2002). Treatment Guidelines for Healthcare Providers' Interventions with Domestic Violence Victims: Experience from the USA. International Journal of Gynecology and Obstetrics 78(SUPPL. 1), 49-54.

Chan, H.C.O., \& Wong, R.W.Y. (2019). Childhood and Adolescent Animal Cruelty and Subsequent Interpersonal Violence in Adulthood: A Review of the Literature. Aggression and Violent Behavior 48(1), 83-93. https://doi.org/10.1016/j.avb.2019.08.007.

Clark, C.J, etal. (2014). Trauma-Sensitive Yoga as an Adjunct Mental Health Treatment in Group Therapy for Survivors of Domestic Violence: A Feasibility Study. Complementary Therapies in Clinical Practice 20(3), 152-158. http://dx.doi.org/10.1016/j.ctcp.2014.04.003.

Cobos-Cali, M., Ladera, V., Perea, M.V., \& García, R. (2018). Language Disorders in Victims of Domestic Violence in Children's Homes. Child Abuse and Neglect 86(2), 384-392. http://dx.doi.org/10.1016/j.chiabu.2017.02.028.

Coutinho, E, et al. (2015). Factors Related to Domestic Violence in Pregnant Women. Procedia-Social and Behavioral Sciences 171, 1280-1287. http://dx.doi.org/10.1016/j.sbspro.2015.01.242.

Erum, J.V, Dam, D.V., \& Deyn, P.P.D. (2019). Jo Ur Na 1 P Of. Neuroscience and Biobehavioral Reviews: 100632. https://doi.org/10.1016/j.neubiorev.2019.07.019.

Fanslow, J. (2017). Intimate Partner Violence and Women's Reproductive Health. Obstetrics, Gynaecology and Reproductive Medicine 27(5), 148-157. https://doi.org/10.1016/j.ogrm.2019.09.003.

Juliana, R. \& Arifin, R. (2019). Anak dan Kejahatan (Faktor Penyebab dan Perlindungan Hukum). Jurnal Selat 6(2), 225-234. DOI: https://doi.org/10.31629/selat.v6i2.1019.

Kang, H.J. (2017). Supportive Music and Imagery with Sandplay for Child Witnesses of Domestic Violence: A Pilot Study Report. Arts in Psychotherapy 53(1). 72-79. http://dx.doi.org/10.1016/j.aip.2017.01.009.

Kemala Dewi, M., \& Arifin, R. (2019). Emancipation and Legal Justice; Portrait of Women's Legal Protection in Indonesia. Jurnal Cita Hukum, 7(1), 101-114. DOI: https://doi.org/10.15408/jch.v7il.10261.

Laeheem, K. (2016). Factors Affecting Domestic Violence Risk Behaviors among Thai Muslim Married Couples in Satun Province. Kasetsart Journal of Social Sciences 37(3), 182-89. http://dx.doi.org/10.1016/j.kjss.2016.08.008.

Laeheem, K. (2017). The Effects of Happy Muslim Family Activities on Reduction of Domestic Violence against Thai-Muslim Spouses in Satun Province. Kasetsart Journal of Social Sciences 38(2), 150-155. http://dx.doi.org/10.1016/j.kjss.2016.05.004. 
Mastorakos, T., \& Scott, K.L. (2019). Attention Biases and Social-Emotional Development in Preschool-Aged Children Who Have Been Exposed to Domestic Violence. Child Abuse and Neglect 89(1), 78-86. https://doi.org/10.1016/j.chiabu.2019.01.001.

La Mattina, G. (2017). Civil Conflict, Domestic Violence, and Intra-Household Bargaining in Post-Genocide Rwanda. Journal of Development Economics 124(1), 168198. http://dx.doi.org/10.1016/j.jdeveco.2016.08.001.

Mukashema, I. (2014). Facing Domestic Violence for Mental Health in Rwanda: Opportunities and Challenges. Procedia-Social and Behavioral Sciences 140, 591-598. http://dx.doi.org/10.1016/j.sbspro.2014.04.476.

Muntamah, A.L., Latifiani, D., \& Arifin, R. (2019). Pernikahan Dini Di Indonesia: Faktor dan Peran Pemerintah (Perspektif Penegakan dan Perlindungan Hukum Bagi Anak). Widya Yuridika 2(1), 1-12. DOI: https://doi.org/10.31328/wy.v2il.823.

Özçakar, N., Yeşiltepe, G., Karaman, G., \& and Ergönen, A.T. (2016). Domestic Violence Survivors and Their Experiences during Legal Process. Journal of Forensic and Legal Medicine 40(1), 1-7.

Patrika, S., Verma, A.K., Bhatti, V.K., \& Shatabdi, S. (2012). Measuring Domestic Violence in Human Immunodeficiency Virus-Positive Women. Medical Journal Armed Forces India 68(2), 136-141. http://dx.doi.org/10.1016/S0377-1237(12)60020-3.

Prenzler, T., \& Fardell, L. (2017). Situational Prevention of Domestic Violence: A Review of Security-Based Programs. Aggression and Violent Behavior 34(1), 51-58. http://dx.doi.org/10.1016/j.avb.2017.04.003.

Ragavan, M.I., Fikre, F., Millner, U., \& Bair-Merritt, M. (2018). The Impact of Domestic Violence Exposure on South Asian Children in the United States: Perspectives of Domestic Violence Agency Staff. Child Abuse and Neglect 76(11): 250-260. https://doi.org/10.1016/j.chiabu.2017.11.006.

Reif, K., \& Jaffe, P. (2019). Remembering the Forgotten Victims: Child-Related Themes in Domestic Violence Fatality Reviews. Child Abuse and Neglect 98(9), 350362.

Riedl, D., et al. (2019). Violence from Childhood to Adulthood: The Influence of Child Victimization and Domestic Violence on Physical Health in Later Life. Journal of Psychosomatic Research 116(11), 68-74. https://doi.org/10.1016/j.jpsychores.2018.11.019.

Ruddle, A., Pina, A., \& Vasquez, E. (2017). Domestic Violence Offending Behaviors: A Review of the Literature Examining Childhood Exposure, Implicit Theories, Trait Aggression and Anger Rumination as Predictive Factors. Aggression and Violent Behavior 34(1), 154-165. http://dx.doi.org/10.1016/j.avb.2017.01.016.

Sánchez-Guzmán, Alejandra, M., Paz-Rodríguez, F., Santos, Z.T.D.L, \& EspinolaNadurille, M. (2017). Domestic Violence among Persons with Epilepsy and Their 
Caregivers. Epilepsy and Behavior 71(1), 85-93.

Sartin, R.M., Hansen, D.J., \& Huss, M.T. (2006). Domestic Violence Treatment Response and Recidivism: A Review and Implications for the Study of Family Violence. Aggression and Violent Behavior 11(5), 425-440.

Schumacher, J.A., Falls-Stewart, W., \& Leonard, K.E. (2003). Domestic Violence Treatment Referrals for Men Seeking Alcohol Treatment. Journal of Substance Abuse Treatment 24(3), 279-283.

Schumacher, J.A., \& Holt, D.J. (2012). Domestic Violence Shelter Residents' Substance Abuse Treatment Needs and Options. Aggression and Violent Behavior 17(3), 188-197. http://dx.doi.org/10.1016/j.avb.2012.01.002.

Setyaningrum, A., Arifin, R. (2019). Analisis Upaya Perlindungan dan Pemulihan Terhadap Korban Kekerasan dalam Rumah Tangga (KDRT) Khususnya AnakAnak dan Perempuan. JURNAL MUVODDIMAH: Jurnal Ilmu Sosial, Politik dan Hummaniora 3(1), 9-19. Retrieved from http://jurnal.umtapsel.ac.id/index.php/muqoddimah/article/view/677.

Soonok, A. et al. (2017). The Effectiveness of Intervention for Adolescents Exposed to Domestic Violence. Children and Youth Services Review 79(1), 132-138. http://dx.doi.org/10.1016/j.childyouth.2017.05.031.

Stevens, C., et al. (2019). Detecting and Reducing Post-Traumatic Stress among Children Exposed to Domestic Violence: A Multi-Agency Early Intervention Program. Children and Youth Services Review 101(3), 261-269. https://doi.org/10.1016/j.childyouth.2019.03.055.

Tarquinio, C. et al. (2012). Eye Movement Desensitization and Reprocessing (EMDR) Therapy in the Treatment of Victims of Domestic Violence: A Pilot Study. Revue Europeenne de Psychologie Applique 62(4), 205-212. http://dx.doi.org/10.1016/j.erap.2012.08.006. 